\title{
Metabolic syndrome, diabetes and inadequate lifestyle in first-degree relatives of acute myocardial infarction survivors younger than $45 \mathrm{yrs}$. old
}

\author{
Maria Helane da Costa Gurgel Castelo, Renan Magalhães Montenegro Junior*, Clarisse Mourão Melo Ponte, \\ Tamara Cristina S Sousa, Paulo Goberlanio B Silva, Lucia de Sousa Belém, Alexandre C Pereira, \\ Raul Dias Santos Filho
}

From 20th Brazilian Diabetes Society Congress

Porto Alegre, Brazil. 11-18 November 2015

\section{Background}

Acute Myocardial infarction (AMI) before the age of 45 is unusual and is associated with a familial component. This study evaluated cardiovascular risk factors in a crosssectional study of first-degree relatives of Brazilian patients with premature MI.

\section{Materials and methods}

A total of 166 first-degree relatives (FDR) of 103 patients with MI age $<45$ yrs. were matched for sex and age with a group of 111 individuals with no family history of cardiovascular disease (control group). Familial hypercholesterolemia was excluded. Patients were evaluated for the presence of metabolic syndrome, its components, and lifestyle (smoking, alcohol consumption, and sedentarism). Laboratory analysis included fasting blood glucose, plasma lipids and thyrotropin (TSH).

\section{Results}

The prevalences of smoking ( 29.5 vs. $6.3 \%, \mathrm{p}<0.001)$, prediabetes ( 40.4 vs. $27, \mathrm{p}<0.001)$, diabetes $(19.9$ vs. $1.8 \%$, $\mathrm{p}<0.001)$, metabolic syndrome (64.7 vs. $36 \%, \mathrm{p}<0.001)$, and dyslipidaemia ( $84.2 \times 31.2 \%$, p: 0.001$)$ were higher in FDR individuals. Triglycerides $(179 \pm 71$ vs. $140 \pm 74 \mathrm{mg} / \mathrm{dL}$, p: 0.002), LDL-cholesterol $(122 \pm 36 \mathrm{vs} .113 \pm 35 \mathrm{mg} / \mathrm{dL}$, p: $0.031)$, non-HDL cholesterol $(157 \pm 53 \mathrm{vs} .141 \pm 41 \mathrm{mg} / \mathrm{dL}$, p: 0.004$)$, and TSH levels $(2.4 \pm 1.6$ vs. $1.9 \pm 1.0$, p: 0.002$)$ were also higher, and HDL-cholesterol $(39 \pm 10$ vs. 48 $\pm 14 \mathrm{mg} / \mathrm{dL}, \mathrm{p}<0.001)$ lower in FDR. No significant differences were observed between groups for body mass

Faculdade de Medicina da universidade Federal do Ceará, Fortaleza, Brazil index, abdominal obesity, hypertension, total cholesterol, and fasting blood glucose levels.

\section{Conclusions}

FDR of patients with AMI < age of 45 yrs. old without familial hypercolesterolemia present elevated prevalence of the metabolic syndrome and its components, as well as an inadequate lifestyle.

Published: 11 November 2015

\section{doi:10.1186/1758-5996-7-S1-A161}

Cite this article as: da Costa Gurgel Castelo et al:: Metabolic syndrome, diabetes and inadequate lifestyle in first-degree relatives of acute myocardial infarction survivors younger than $45 \mathrm{yrs}$. old. Diabetology \& Metabolic Syndrome 2015 7(Suppl 1):A161.
Submit your next manuscript to BioMed Central and take full advantage of:

- Convenient online submission

- Thorough peer review

- No space constraints or color figure charges

- Immediate publication on acceptance

- Inclusion in PubMed, CAS, Scopus and Google Scholar

- Research which is freely available for redistribution

Submit your manuscript at www.biomedcentral.com/submit
() Biomed Central 